\title{
PERFORMA KOMODITAS BUDIDAYA LAUT PADA SISTEM INTEGRATED MULTI-TROPHIC AQUACULTURE (IMTA) DI TELUK GERUPUK, LOMBOK TENGAH, NUSA TENGGARA BARAT
}

\author{
I Nyoman Radiarta\# dan Erlania \\ Pusat Penelitian dan Pengembangan Perikanan
}

\begin{abstract}
ABSTRAK
Budidaya laut berbasis Integrated Multi-Trophic Aquaculture (IMTA) merupakan opsi pengembangan budidaya perikanan yang sejalan dengan konsep pelestarian lingkungan. Tujuan penelitian ini adalah menganalisis performa komoditas budidaya laut yang pada sistem integrated multi-trophic aquaculture (IMTA). Penelitian dilaksanakan di Teluk Gerupuk, Lombok Tengah, Nusa Tenggara Barat, pada bulan Juni-November 2015. Model IMTA yang dikembangkan adalah kombinasi antara ikan kerapu macan (Epinephelus fuscoguttatus), ikan bawal bintang (Trachinotus blochii, Lacepede), dan rumput laut (Kappaphycus alvarezii). Hasil penelitian menunjukkan bahwa selama 150 hari masa pemeliharaan ikan kerapu dan bawal bintang menghasilkan pertumbuhan yang baik, dengan rata-rata bobot akhir ikan kerapu sebesar 173,45 \pm 36,61 g/ekor; dan ikan bawal bintang sebesar 161,27 \pm 30,05 g/ekor. Pertumbuhan rumput laut selama tiga siklus menunjukkan bahwa siklus pertama (Juni-Juli) dan siklus kedua (Agustus-September) menghasilkan pertumbuhan yang lebih baik dibandingkan dengan siklus ketiga (Oktober-November). Laju pertumbuhan harian rumput laut di sekitar keramba jarring apung (KJA) ikan sebesar 4,22\%-6,09\%/hari lebih tinggi dibandingkan dengan kontrol (jarak 2-3 km dari KJA ikan) yaitu 3,90\%-5,53\%/hari. Hasil dari penelitian ini menunjukkan efektivitas sistem IMTA dalam hal peningkatan produktivitas budidaya rumput laut. Model IMTA dapat diterapkan sebagai model pengembangan budidaya laut yang berwawasan lingkungan melalui peningkatan produksi, sistem produksi bersih, dan berkelanjutan.
\end{abstract}

KATA KUNCI: $\quad$ performa pertumbuhan; rumput laut; budidaya laut; IMTA; Teluk Gerupuk; Nusa Tenggara Barat

ABSTRACT: Performance of mariculture commodities under Integrated Multi-Trophic Aquaculture (IMTA) system at Gerupuk Bay, Central Lombok, West Nusa Tenggara. By: I Nyoman Radiarta and Erlania

Mariculture activity with Integrated Multi-Trophic Aquaculture (IMTA) is an aquaculture development technique which in line with environment conservation concept. This study was aimed to analyze perfomance of mariculture commodities that cultured under integrated multi-trophic aquaculture (IMTA) system. The study was conducted in Gerupuk Bay, Central Lombok, West Nusa Tenggara during June-November 2015. The IMTA model was combined between tiger grouper fish (Epinephelus fuscoguttatus), silver pompano fish (Trachinotus blochii, Lacepede), and seaweed (Kappaphycus alvarezii). The result showed that during 150 days of cultured periods, both of grouper and pompano indicated a good growth performance, with mean body weight at the end of culture period about $173.45 \pm 36.61 \mathrm{~g} / \mathrm{ind}$. and 161.27 $\pm 30.05 \mathrm{~g} / \mathrm{ind}$., respectively. Seaweed growth performance from three cultivation cycles showed that cycle-1 (JuneJuly) and cycle-2 (August-September) had better growth performance than cycle-3 (October-November). Daily growth rate of seaweed that cultured near fish cages was higher (4.22\%-6.09\%) than control, 2-3 km distance to fish cages (3.90\%-5.53\%). This study indicated the effectiveness of IMTA system to increase seaweed culture production. IMTA model can be applied as development model of mariculture with environmental concept through production enhancement, zero waste production, and sustainability.

KEYWORDS: $\quad$ growth performance; seaweeds; mariculture; IMTA; Gerupuk Bay; West Nusa Tenggara

\footnotetext{
\# Korespondensi: Pusat Penelitian dan Pengembangan

Perikanan. Jl. Pasir Putih II, Ancol Timur-Jakarta Utara 14430.

Tel.: + (021) 64700928

E-mail: radiarta@yahoo.com
} 


\section{PENDAHULUAN}

Aktivitas budidaya perikanan yang berkembang dengan pesat dapat menimbulkan pencemaran terhadap lingkungan dan mengganggu keseimbangan ekosistem. Salah satu strategi pengembangan perikanan budidaya yaitu pemilihan lokasi yang sesuai dan tingkat teknologi yang adaptif, yang merupakan langkah awal untuk menjamin usaha budidaya yang berkelanjutan (Costa-Pierce, 2008). Penggunaan metode budidaya yang tepat dapat mendorong perkembangan sistem budidaya perikanan dengan tingkat produktivitas yang tinggi dan sistem operasi yang ramah lingkungan. Budidaya perikanan secara terintegrasi (integrated multi-trophic aquaculture/IMTA) merupakan inovasi pengembangan sistem budidaya perikanan, jika dibandingkan dengan budidaya perikanan konvensional hanya menggunakan satu spesies budidaya saja. Budidaya terintegrasi ini memadukan beberapa spesies yang memiliki tingkat trofik yang berbeda antara spesies yang diberi pakan (misalnya ikan) dengan spesies penyerap bahan anorganik (misalnya rumput laut), dan spesies penyerap bahan organik (suspension dan deposit feeder, seperti kekerangan) (Troell et al., 2009; Barrington et al., 2009). Penerapan sistem IMTA ini tidak hanya menghasilkan biomassa yang bernilai ekonomis tinggi melalui diversifikasi produk, namun juga dapat mengurangi limbah yang masuk ke dalam perairan. Pada sistem IMTA, limbah yang dihasilkan dari komoditas utama yang masuk ke dalam perairan akan dikonversi dan dimanfaatkan oleh spesies penyerap bahan organik dan anorganik.

Sistem IMTA diterapkan untuk menjawab tantangan mengenai isu dampak aktivitas budidaya terhadap lingkungan perairan yang meliputi sedimentasi dan pengkayaan nutrien perairan (Radiarta et al., 2014; 2015; Alexander et al., 2016). Efektivitas sistem IMTA ini telah di-review oleh FAO untuk ekosistem payau (Troell, 2009) dan laut (Barrington et al., 2009). Untuk ekosistem laut, penelitian tentang aplikasi sistem IMTA cukup banyak dilakukan yang meliputi: (1) aspek pemanfaatan nutrien dari beberapa komoditas budidaya (Lander et al., 2013; Tang et al., 2015; Irisarri et al., 2015), (2) aspek produktivitas komoditas yang dibudidayakan (Neori et al., 2000; Radiarta et al., 2014), dan (3) aspek sosial dan ekonomi (Martinez-Espineira et al., 2015; Alexander et al., 2016). Pemilihan komoditas untuk sistem IMTA sangat fleksibel, dapat disesuaikan dengan komoditas yang telah berkembang pada suatu kawasan baik itu ikan, rumput laut, ataupun kekerangan. Komoditas yang dipilih tersebut disesuaikan dengan fungsinya dalam ekosistem dan merupakan komoditas dengan nilai ekonomis yang tinggi. Dengan pemilihan spesies budidaya yang benar, sistem IMTA ini akan mereduksi kandungan organik dan anorganik nitrogen, karbon, dan fosfat; menjadikan sistem ini sebagai kandidat dalam nutrient trading credits (Chopin et al., 2010; Yuniarsih et al., 2014).

Perkembangan budidaya laut saat ini menunjukkan tren yang terus meningkat seiring dengan peningkatan kebutuhan protein manusia. Tantangan yang ada, adalah bagaimana meningkatkan produktivitas budidaya laut pada suatu kawasan ketika pilihan teknologi yang ada menjadi suatu kendala. Peluang yang dapat digunakan adalah meningkatkan level teknologi yang digunakan dengan memperhatikan limbah yang dihasilkan sehingga tidak merusak lingkungan. Penerapan sistem IMTA merupakan satu jawaban dari teknologi yang tersedia (Soto, 2009). Performa pertumbuhan spesies budidaya melalui IMTA menunjukkan hasil yang sangat baik terutama spesies penyerap bahan anorganik, seperti rumput laut, dan spesies penyerap bahan organik, seperti kekerangan. Melalui konsep IMTA yang diterapkan di Kanada, laju pertumbuhan kerang dan rumput laut (kelp) yang berlokasi di sekitar KJA ikan laut menunjukkan pertumbuhan masing-masing sebesar $46 \%$ dan $50 \%$ lebih besar dari kontrol (Chopin \& Robinson, 2006). Penelitian lainnya (Troell et al., 1997), menunjukkan laju pertumbuhan rumput laut yang diletakkan sekitar $10 \mathrm{~m}$ dari unit KJA ikan 40\% lebih tinggi dibandingkan dengan rumput laut yang diletakkan dengan jarak 150 $\mathrm{m}$ dan $1 \mathrm{~km}$ dari KJA. Peningkatan pertumbuhan rumput laut dan kekerangan ini menunjukkan adanya peningkatan konsentrasi nutrien organik dan anorganik yang berasal dari KJA ikan laut.

Teluk Gerupuk dengan luasan sekitar 940 ha, merupakan kawasan perairan yang dimanfaatkan untuk berbagai aktivitas diantaranya perikanan tangkap, perikanan budidaya (budidaya rumput laut, lobster, dan ikan laut), dan pariwisata (wisata surfing). Dari total area potensial untuk pengembangan budidaya laut (826 ha), menunjukkan bahwa kawasan dengan kategori sangat sesuai untuk budidaya ikan dengan KJA dan rumput laut adalah masing-masing sebesar 374 ha dan 364 ha (Radiarta, 2015). Berdasarkan analisis daya dukung kawasan maka luasan area untuk budidaya rumput laut adalah 339,5 ha dengan jumlah unit rakit ukuran 7 m x 7 m sebanyak 4.658 unit; sedangkan untuk budidaya ikan laut total area yang dapat digunakan sesuai dayang dukung adalah seluas 120,48 ha (Radiarta, 2015). Model pengembangan budidaya laut yang sudah ada di teluk ini adalah budidaya rumput laut jenis Kappaphycus alvarezii dengan menggunakan rakit dan long line, namun jumlahnya masih sangat sedikit. Demikian pula dengan exsisting KJA yang ada hanya beberapa unit yang dikelola oleh Balai Perikanan Budidaya Laut (BPBL) Lombok di Gerupuk. Penerapan budidaya terintegrasi sangat sesuai untuk perairan 
Teluk Gerupuk, karena pemanfaatan lahan yang cukup kompleks di kawasan tersebut. Penelitian ini bertujuan untuk menganalisis performa komoditas budidaya laut yang diterapkan melalui sistem budidaya laut terintegrasi atau integrated multi-trophic aquaculture (IMTA).

\section{BAHAN DAN METODE}

Penelitian ini dilaksanakan di Teluk Gerupuk, Lombok Tengah, Nusa Tenggara Barat (Gambar 1a). Teluk Gerupuk merupakan percontohan kawasan blue economy Kementerian Kelautan dan Perikanan/KKP (KKP, 2014). Selain itu, teluk ini juga merupakan

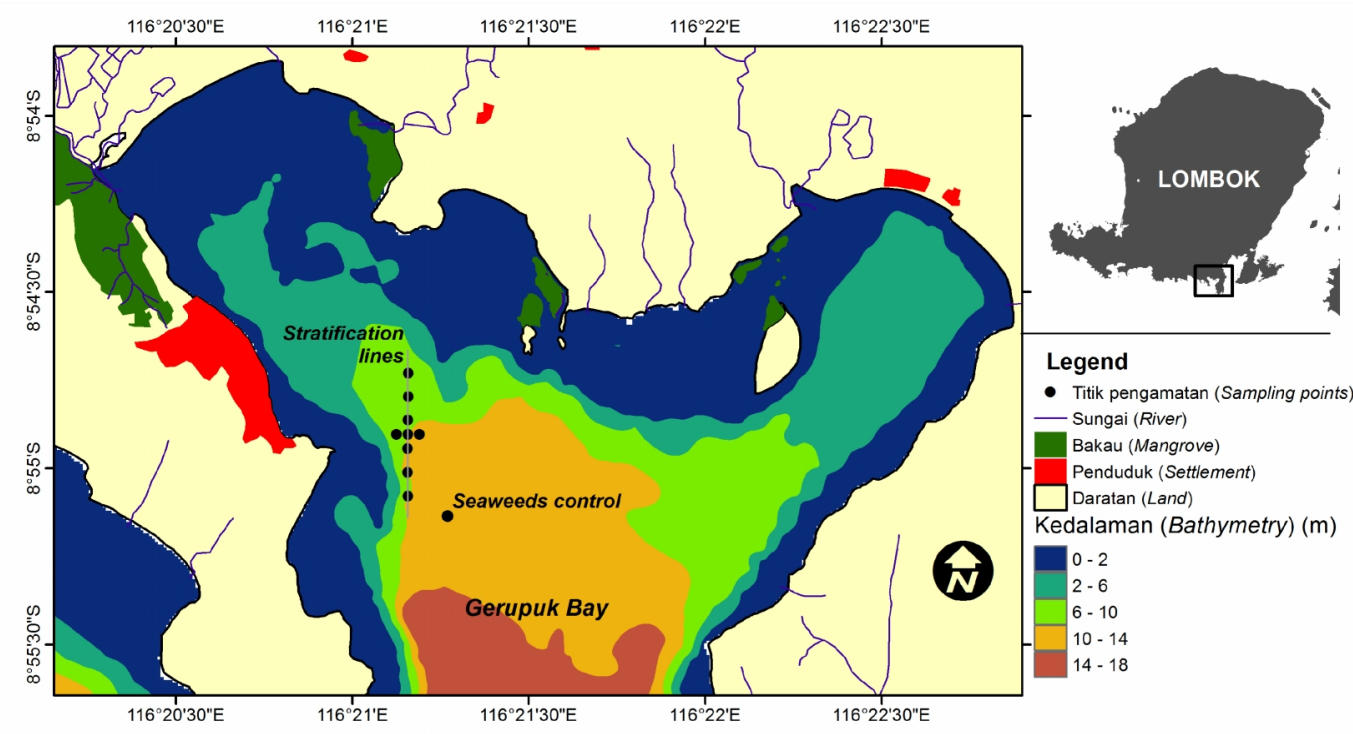

(a)

Rumput Laut (seaweed) $7 x 7 \mathrm{~m} /$ unit

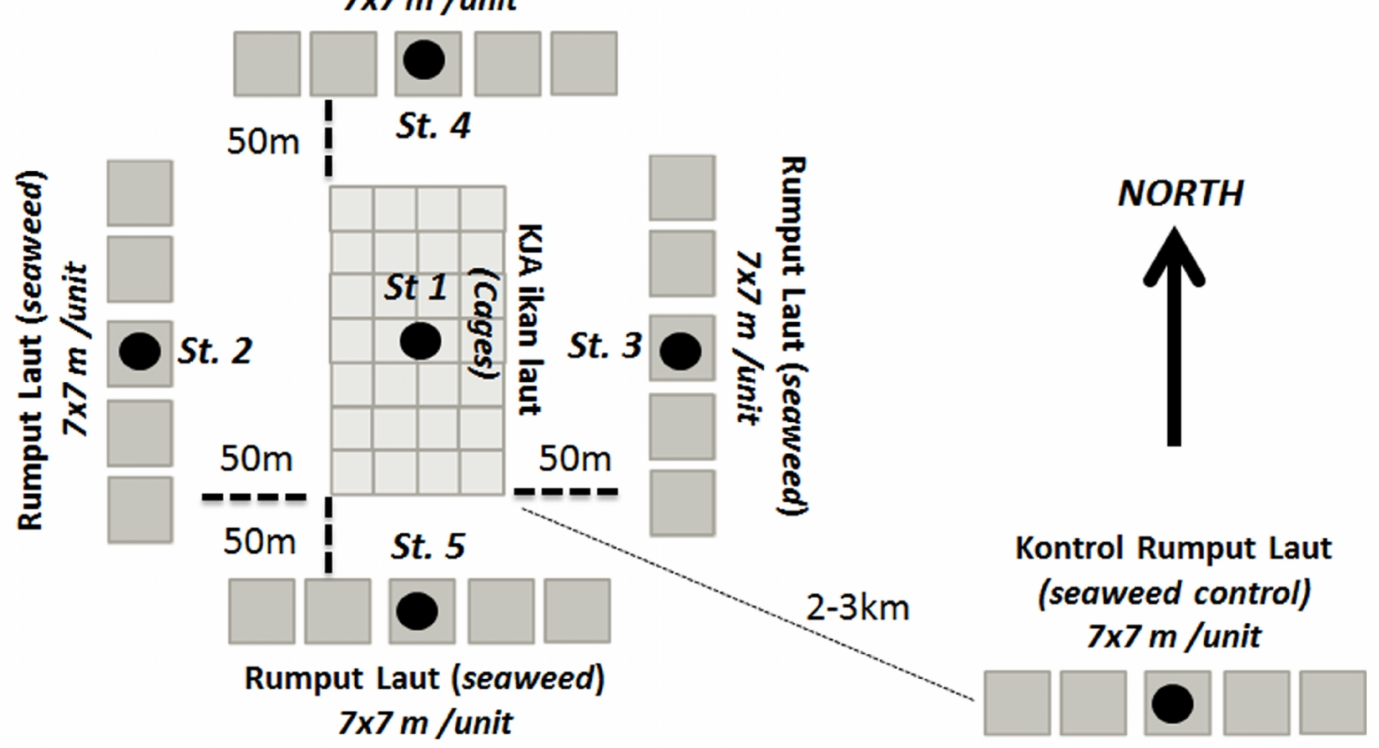

(b)

St. kontrol

Gambar 1. Lokasi penelitian di Teluk Gerupuk, Lombok Tengah, Nusa Tenggara Barat: (a) sebaran titik pengamatan (garis yang menghubungkan titik menunjukkan pengamatan secara stratifikasi) dan (b) model pengembangan sistem IMTA

Figure 1. Study site at Gerupuk Bay, Central Lombok, West Nusa Tenggara: (a) distribution of sampling points (line indicates stratification stations) and (b) development model of IMTA system 
kawasan minapolitan nasional dan program PIJAR (sapijagung-rumput laut) Provinsi NTB dengan komoditas unggulannya adalah rumput laut (Anonim, 2011). Topografi teluk ini cukup landai, luasan teluk mencapai 940 ha dan kedalaman maksimum sekitar $17 \mathrm{~m}$ pada saat pasang surut (pasut) rata-rata. Sisi dalam teluk merupakan kawasan intertidal, di mana saat surut terendah kawasan ini menjadi kering. Tipe pasut untuk Teluk Gerupuk adalah campuran condong ke semi-diurnal, dengan tunggang pasut mencapai 2,85 m (Tarunamulia et al., 2015).

\section{Model Budidaya Laut Terintegrasi}

Model IMTA yang diterapkan di lokasi penelitian merupakan kombinasi antara ikan laut dan rumput laut (Gambar 1b). Ikan dibudidayakan pada keramba jaring apung (KJA) yang menjadi pusat dari sistem IMTA (posisi: $116.35262^{\circ} \mathrm{BT}$; $-8.91507^{\circ} \mathrm{LS}$ ), sedangkan rumput laut dibudidayakan menggunakan rakit apung yang disebar di sekeliling KJA, yaitu pada sisi Barat (stasiun 2), Timur (stasiun 3), Utara (stasiun 4), dan Selatan (stasiun 5) KJA (Gambar 1b). Jenis ikan yang digunakan sebagai komoditas utama dari sistem IMTA ini adalah ikan kerapu macan (Epinephelus fuscoguttatus) dan bawal bintang (Trachinotus blochii). Ikan kerapu dibudidayakan pada enam lubang dan bawal pada tiga lubang KJA yang masing-masing ukuran $4 \mathrm{~m}$ x $4 \mathrm{~m}$ x 3 $m$. Setiap lubang KJA diisi sebanyak 500 ekor dengan rata-rata bobot awal ikan kerapu macan sekitar 29,53 $\pm 3,20 \mathrm{~g}$ (7-8 cm/ekor) dan ikan bawal bintang sekitar 7,67 $\pm 2,29 \mathrm{~g}$ (11-12 cm/ekor). Pemeliharaan ikan dilakukan selama lima bulan (150 hari). Dalam penerapan IMTA hanya komoditas utama yang diberi pasokan pakan yaitu ikan kerapu dan bawal bintang. Sedangkan komoditas lainnya akan memanfaatkan sisa pakan yang tidak termakan dan terbuang ke perairan, yang sebagian juga akan terurai baik dalam bentuk particulate organic matter (POM) dan dissolved inorganic nutrient (DIN) yang dapat dimanfaatkan oleh rumput laut (Barrington et al., 2009). Pakan yang digunakan dalam penelitian ini adalah pakan pelet komersial dan ikan rucah. Pakan diberikan dua kali sehari yaitu pagi dan sore hari dengan ukuran pelet sesuai dengan ukuran ikan yang dibudidayakan. Pemberian pakan dilakukan dengan feeding rate $2 \%-5 \%$ dari biomassa ikan secara ad libitum (sampai kenyang).

Selain dua jenis ikan sebagai komoditas budidaya utama yang digunakan dalam model IMTA ini, juga dilakukan budidaya rumput laut (Kappaphycus alvarezii) sebagai komoditas sekunder yang sekaligus berperan dalam menyerap bahan organik yang dihasilkan dari aktivitas budidaya ikan. Rumput laut dibudidayakan dengan sistem rakit apung dengan ukuran $7 \mathrm{~m} \mathrm{x} 7 \mathrm{~m}$. Pada keempat sisi KJA diposisikan masing-masing lima rakit dengan jarak sekitar $50 \mathrm{~m}$ dari KJA. Lima rakit lainnya ditempatkan pada lokasi yang relatif jauh dari aktivitas budidaya ikan sebagai kontrol, yang terletak sekitar 2-3 km dari KJA IMTA ke arah tengah teluk (Gambar 1b). Pemeliharaan rumput laut dilakukan selama tiga siklus (siklus I: bulan Juni-Juli; Siklus II: bulan Agustus-September, dan siklus III: bulan OktoberNovember), masing-masing siklus selama 45 hari.

\section{Pengumpulan Data}

Pegumpulan data dilakukan pada bulan Juni-November 2015. Data yang dikumpulkan meliputi data pertumbuhan komoditas budidaya (ikan bawal bintang, ikan kerapu, dan rumput laut). Pengamatan pertumbuhan dilakukan setiap 15 hari sekali terhadap komoditas yang dibudidayakan. Contoh ikan diambil 15 ekor dari setiap lubang KJA IMTA ( $n=15)$ untuk pengukuran bobot dan panjang ikan. Untuk rumput laut, sebanyak lima titik contoh diambil secara acak $(\mathrm{n}=5)$ dari rakit rumput laut pada setiap stasiun pengamatan; kemudian diukur bobot dari masingmasing contoh. Pengamatan rumput laut dilakukan selama tiga siklus musim tanam, yaitu siklus pertama bulan Juni-Juli, siklus kedua bulan Agustus-September, dan siklus ketiga bulan Oktober-November. Selain data pertumbuhan komoditas budidaya, data kondisi perairan juga diamati. Pengamatan kualitas perairan dilakukan secara stratifikasi pada tiga kedalaman yaitu dekat permukaan, tengah, dan dekat dasar perairan, pada tujuh titik pengamatan yang berada pada garis melintang dari bagian Utara ke Selatan KJA, dengan jarak antar titik pengamatan sekitar $50 \mathrm{~m}$ (Gambar 1a). Pengukuran kualitas perairan dilakukan langsung di lapangan dengan menggunakan multi-parameter water quality checker Horiba U-50 yang meliputi: suhu, salinitas, dan kekeruhan.

\section{Analisis Data}

Data pertumbuhan komoditas budidaya (ikan kerapu macan, bawal bintang, dan rumput laut) yang digunakan pada penelitian ini berupa bobot dan panjang total ikan yang dianalisis secara deskriptif dan ditampilkan dengan grafik. Tren pertumbuhan masingmasing komoditas juga dianalisis menggunakan beberapa perhitungan meliputi: laju pertumbuhan spesifik (specific growth rate/SGR) ikan, rasio konversi pakan (food convertion ratio/FCR), dan sintasan; serta laju pertumbuhan harian (daily growth rate/DGR) rumput laut (Lüning, 1990; Dawes, 1993; Effendie, 1979; Neori et al., 2000).

Laju pertumbuhan spesifik ikan kerapu macan dan bawal bintang dihitung menggunakan formula berikut:

$$
\operatorname{SGR}(\% / \text { hari })=\frac{\left(\operatorname{Ln} W_{t}-\operatorname{Ln} W_{o}\right)}{t} \times 100
$$


di mana:

$\mathrm{W}_{\mathrm{t}}$ = bobot basah ikan pada akhir pemeliharaan (g)

$\mathrm{W}_{\mathrm{o}}$ = bobot basah ikan pada awal pemeliharaan (g)

$\mathrm{T}=$ lama pemeliharaan (hari)

Rasio konversi pakan (FCR) untuk budidaya ikan dikalkulasikan dengan persamaan berikut:

$$
\mathrm{FCR}=\left(\frac{\text { Jumlah pakan }}{\text { Pertambahan bobot }}\right)
$$

Sintasan (survival rate/SR) dihitung dengan formula sebagai berikut:

$$
\operatorname{Sintasan}(\%)=\left(\frac{N_{t}}{N_{o}}\right) \times 100
$$

di mana:

$\mathrm{N}_{\mathrm{o}}$ = jumlah ikan pada awal pemeliharaan (ekor)

$\mathrm{N}_{\mathrm{t}}=$ jumlah ikan pada akhir pemeliharaan (ekor)

Laju pertumbuhan harian (daily growth rate/DGR) rumput laut dikalkulasikan berdasarkan persamaan sebagai berikut:

$$
\operatorname{DGR}(\% / \text { hari })=\frac{100 \operatorname{In}\left(\mathrm{W}_{\mathrm{f}} / \mathrm{W}_{\mathrm{o}}\right)}{\mathrm{T}}
$$

di mana:

$\mathrm{W}_{\mathrm{f}}=$ bobot basah rumput laut per titik sampling pada akhir pemeliharaan $(\mathrm{g})$

$\mathrm{W}_{\mathrm{o}}$ = bobot basah rumput laut per titik sampling pada awal tanam (g)

$\mathrm{T} \quad$ = waktu pemeliharaan (hari)

Data kualitas air dianalisis secara spasial yang ditampilkan dalam bentuk vertikal. Perangkat lunak yang digunakan dalam analisis ini adalah Ocean Data View (ODV) (Schlitzer, 2011). Untuk melakukan analisis spasial, seluruh data yang terkumpul diinterpolasi dengan teknik gridded field (VG gridding).

\section{HASIL DAN BAHASAN}

\section{Budidaya Ikan Laut}

Ikan kerapu merupakan ikan ekonomis tinggi yang dijadikan sebagai salah satu komoditas unggulan pada program industrialisasi oleh KKP tahun 2012 sampai sekarang. Produksi ikan kerapu tahun 2014 mencapai 12.400 ton, dan pada tahun 2019 produksi ikan ini ditargetkan mencapai 67.100 ton (Anonim, 2016). Ikan bawal bintang juga termasuk salah satu komoditas budidaya laut bernilai ekonomis tinggi, baik di pasar lokal maupun untuk ekspor dengan harga sekitar
Rp65.000,00-Rp90.000,00 atau sekitar USD 6-8/kg (Dharma et al., 2013). Budidaya ikan bawal bintang ini secara intensif telah berhasil dilakukan sekitar tahun 1970-1974 di perairan pantai Republik Dominika, yang merupakan komoditas laut tropis pertama yang berhasil dibudidayakan secara komersil di belahan dunia Barat. Di Indonesia, spesies ini termasuk komoditas budidaya yang tergolong baru, di mana teknologi budidayanya masih menghadapi berbagai kendala/hambatan (Juniyanto et al., 2008).

Performa pertumbuhan ikan kerapu macan dan ikan bawal bintang sebagai komoditas utama yang dibudidayakan pada KJA dengan sistem IMTA menunjukkan hasil yang baik. Tren pertumbuhan dua komoditas ikan yang dibudidayakan diperlihatkan pada Gambar 2. Hasil pengukuran pertumbuhan ikan kerapu macan yang dipelihara selama 150 hari diperoleh ratarata bobot akhir 173,45 $\pm 36,61 \mathrm{~g} /$ ekor; dan rata-rata bobot akhir ikan bawal bintang sekitar 161,27 $\pm 30,05$ g/ekor. Sedangkan rata-rata panjang total kedua ikan tersebut berturut-turut yaitu 17,37 \pm 1,53 dan 21,61 $\pm 1,05 \mathrm{~cm} /$ ekor. Pola Pertumbuhan kerapu macan umumnya menghasilkan pertambahan bobot yang lebih dominan dibandingkan pertambahan panjang badannya. Kondisi pertumbuhan tersebut juga diperlihatkan pada hasil penelitian Ismi (Ismi et al., 2012), yang menunjukkan hubungan panjang-berat kerapu macan bersifat alometrik negatif.

Berdasarkan parameter bobot rata-rata, pertumbuhan kedua jenis ikan yang dipelihara di KJA pada sistem IMTA di perairan Teluk Gerupuk, secara umum memperlihat tren pertumbuhan yang tersegmentasi menjadi tiga segmen umur pemeliharaan (Gambar 3, Tabel 1). Secara umum, kerapu macan memperlihatkan laju pertumbuhan spesifik (SGR) yang relatif lebih rendah dibandingkan bawal bintang (Tabel 1). Pada kisaran umur 45 hari pertama dan 60 hari berikutnya dari total masa pemeliharan 150 hari, bawal bintang memperlihatkan nilai SGR yang jauh lebih tinggi yaitu berturut-turut $2,63 \%$ dan 2,17\%/hari, dibandingkan kerapu macan yaitu $0,84 \%$ dan $1,07 \%$ /hari. Sedangkan pada 45 hari terakhir kerapu macan menunjukkan tren pertumbuhan yang meningkat dengan SGR 1,67\%/hari; yang lebih tinggi dibandingkan SGR bawal bintang yaitu 1,25\%/hari (Tabel 1). SGR bawal bintang yang diperoleh dari hasil penelitian ini (Tabel 1) tidak jauh berbeda dengan hasil penelitian Jayakumar et al. (2014), yang melalukan pembesaran bawal bintang di tambak air payau. Penelitian Jayakumar dengan rata-rata ukuran tebar bawal bintang sekitar 3,06 cm selama 240 hari (delapan bulan), diperoleh rata-rata bobot akhir 464,65 g/ekor; laju pertumbuhan harian $2,27 \%$ /hari. 

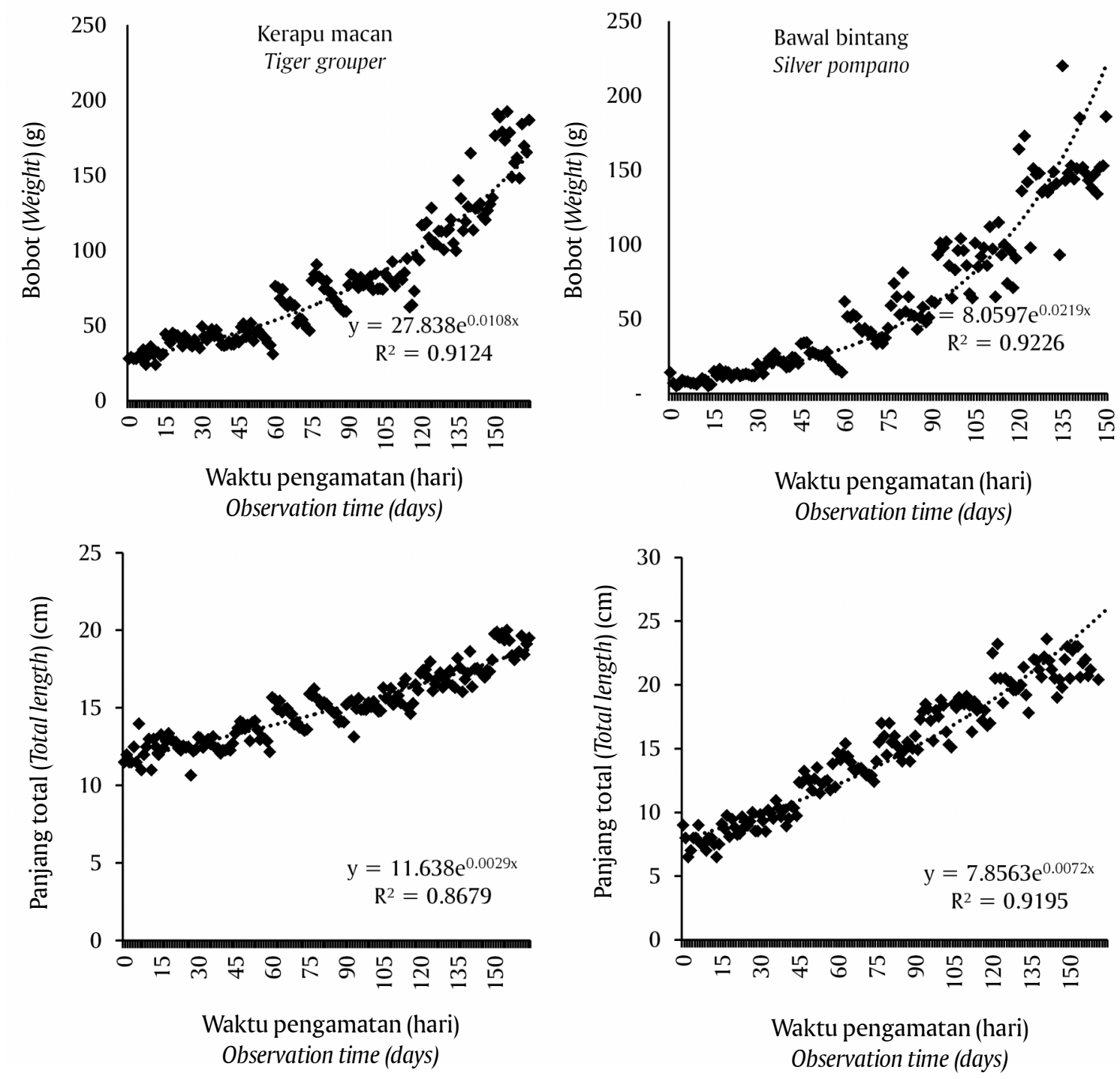

Gambar 2. Performa pertumbuhan ikan kerapu macan dan bawal bintang pada sistem IMTA di Teluk Gerupuk Kabupaten Lombok Tengah, Nusa Tenggara Barat

Figure 2. Growth performance of tiger grouper and silver pompano on IMTA system at Gerupuk Bay, Central Lombok, West Nusa Tenggara

\section{Budidaya Rumput Laut}

Rumput laut adalah produsen utama yang terletak pada bagian bawah sistem trofik, dan banyak digunakan sebagai salah satu komoditas dalam IMTA yang berfungsi sebagai penyerap nutrien. Pertumbuhan rumput laut ini sangat tergantung pada ketersediaan nutrien yang ada di perairan, baik secara alami ataupun yang berasal dari masukan bahan organik ke badan air. Ketersediaan nutrien alami dapat menjadi faktor pembatas, namun adanya nutrien yang berasal dari limbah budidaya ikan dapat membantu pertumbuhan rumput laut, dan pada saat yang bersamaan dapat menghilangkan dampak negatif pengkayaan nutrien dalam lingkungan perairan. Beberapa penelitian telah membuktikan efektivitas rumput laut dalam menyerap nutrien yang berasal dari limbah budidaya ikan laut dalam sistem IMTA (Troell et al., 1997; Hayasi et al., 2008; Reid et al., 2013; Yuniarsih et al., 2014).

Pada penelitian ini, rumput laut jenis Kappaphycus alvarezii telah dibudidayakan dalam unit IMTA bersama dengan ikan laut, yaitu kerapu macan dan bawal bintang. Rumput laut yang dibudidayakan dengan menggunakan rakit apung di sekitar KJA pada sistem IMTA memperlihatkan pertambahan bobot yang relatif lebih besar dan tren pertumbuhan yang lebih baik (meningkat dari awal hingga akhir masa pemeliharaan) jika dibandingkan dengan rumput laut kontrol (Gambar 4). Pertumbuhan rumput laut yang terbagi dalam tiga siklus tanam menunjukkan pola pertumbuhan yang 


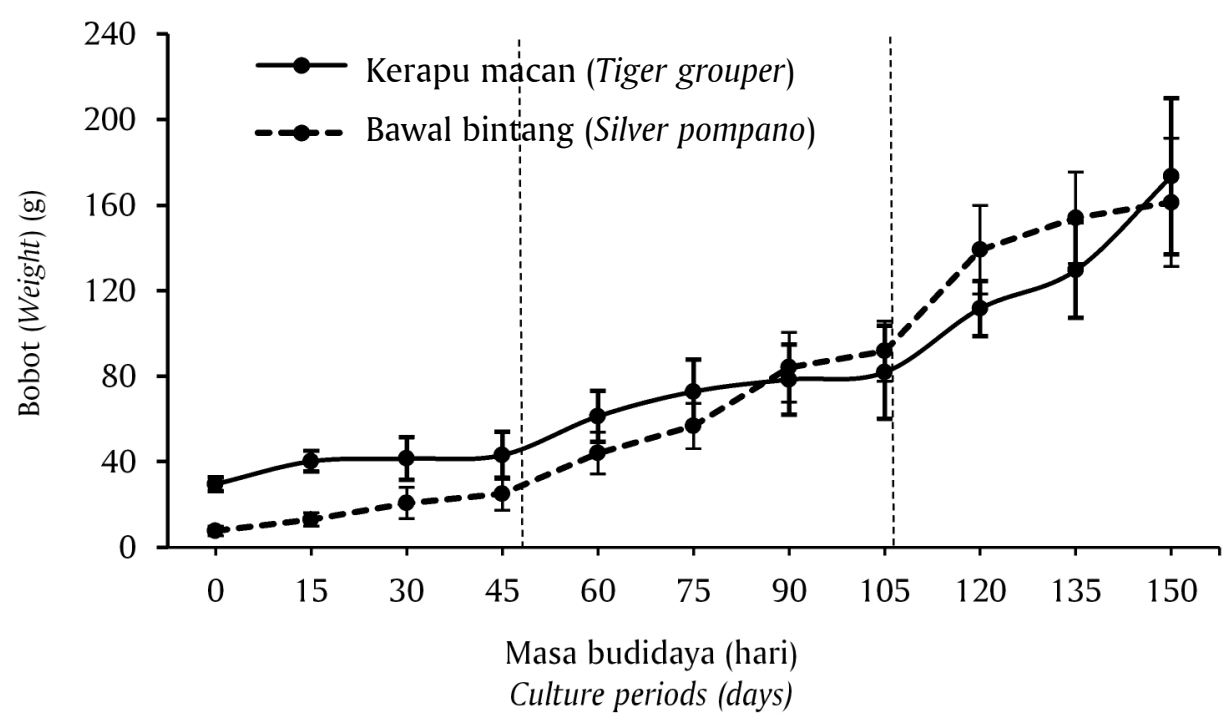

Gambar 3. Pembentuk tiga segmentasi tren pertumbuhan pada pertambahan bobot ikan kerapu macan dan bawal bintang

Figure 3. Three types of growth trend formation by weight increase of tiger grouper and silver pompano

bervariasi berdasarkan lokasi unit rumput laut dalam sistem IMTA (Gambar 4 dan Tabel 2). Siklus pertama (bulan Juni-Juli) dan kedua (bulan Agustus-September) memiliki laju pertumbuhan harian yang lebih baik yaitu masing-masing 5,60\%/hari dan 6,09\%/hari; dibandingkan dengan siklus ketiga (bulan Oktober-November) yaitu $4,22 \% /$ hari (Tabel 2).

Variasi pertumbuhan rumput laut untuk masingmasing unit dalam sistem IMTA (stasiun 2-5) dipengaruhi oleh kondisi arus yang membawa sebaran nutrien dari limbah budidaya ikan (KJA). Pola arus di lokasi penelitian umumnya merupakan arus pasang surut yang banyak dipengaruhi oleh kondisi gelombang dan kecepatan angin. Selain ketersediaan nutrien dalam perairan, kondisi fisik perairan juga dapat memengaruhi laju pertumbuhan rumput laut yang dibudidayakan. Pengamatan kondisi fisik perairan yang meliputi suhu, salinitas, dan kekeruhan secara stratifikasi dari bulan Agustus-November menunjukkan variabilitas lingkungan perairan yang dapat memengaruhi perkembangan rumput laut (Gambar 5). Dari bulan Agustus-November terjadi peningkatan suhu, salinitas, dan kekeruhan perairan, sehingga dapat menghambat pertumbuhan rumput laut (Gambar 4). Hasil pengukuran parameter suhu perairan pada bulan November menunjukkan nilai yang cukup tinggi yaitu sekitar $29^{\circ} \mathrm{C}$. Demikian pula dengan kondisi salinitas (>34 ppt) dan kekeruhan perairan (> $5 \mathrm{NTU}$ ). Kondisi ideal suhu dan salinitas perairan untuk budidaya rumput laut adalah $20^{\circ} \mathrm{C}-28^{\circ} \mathrm{C}$ dan 32 35 ppt (Parenrengi et al., 2011). Peningkatan suhu sampai dengan batas optimum dapat meningkatkan

Tabel 1. Perbedaan laju pertumbuhan spesifik (LPS) ikan kerapu macan dan bawal bintang pada tiga segmentasi waktu pemeliharan

Table 1. The difference of specific growth rate (SGR) of tiger grouper and silver pompano at three segmentation of culture periods

\begin{tabular}{|c|c|c|c|c|}
\hline \multirow{2}{*}{$\begin{array}{l}\text { Komoditas } \\
\text { Species }\end{array}$} & \multirow{2}{*}{$\begin{array}{l}0-150 \text { hari } \\
150 \text { days }\end{array}$} & \multicolumn{3}{|c|}{$\begin{array}{l}\text { Segmen waktu pemeliharan (hari) } \\
\text { Segmentation of cultured periods }\end{array}$} \\
\hline & & $\begin{array}{c}0-45 \\
(45 \text { days })\end{array}$ & $\begin{array}{l}45-105 \\
(60 \text { days })\end{array}$ & $\begin{array}{l}105-150 \\
(45 \text { days })\end{array}$ \\
\hline Kerapu macan (Tiger grouper) & 0.99 & 0.84 & 1.07 & 1.67 \\
\hline Bawal bintang (Silver pompano) & 2.00 & 2.63 & 2.17 & 1.25 \\
\hline
\end{tabular}



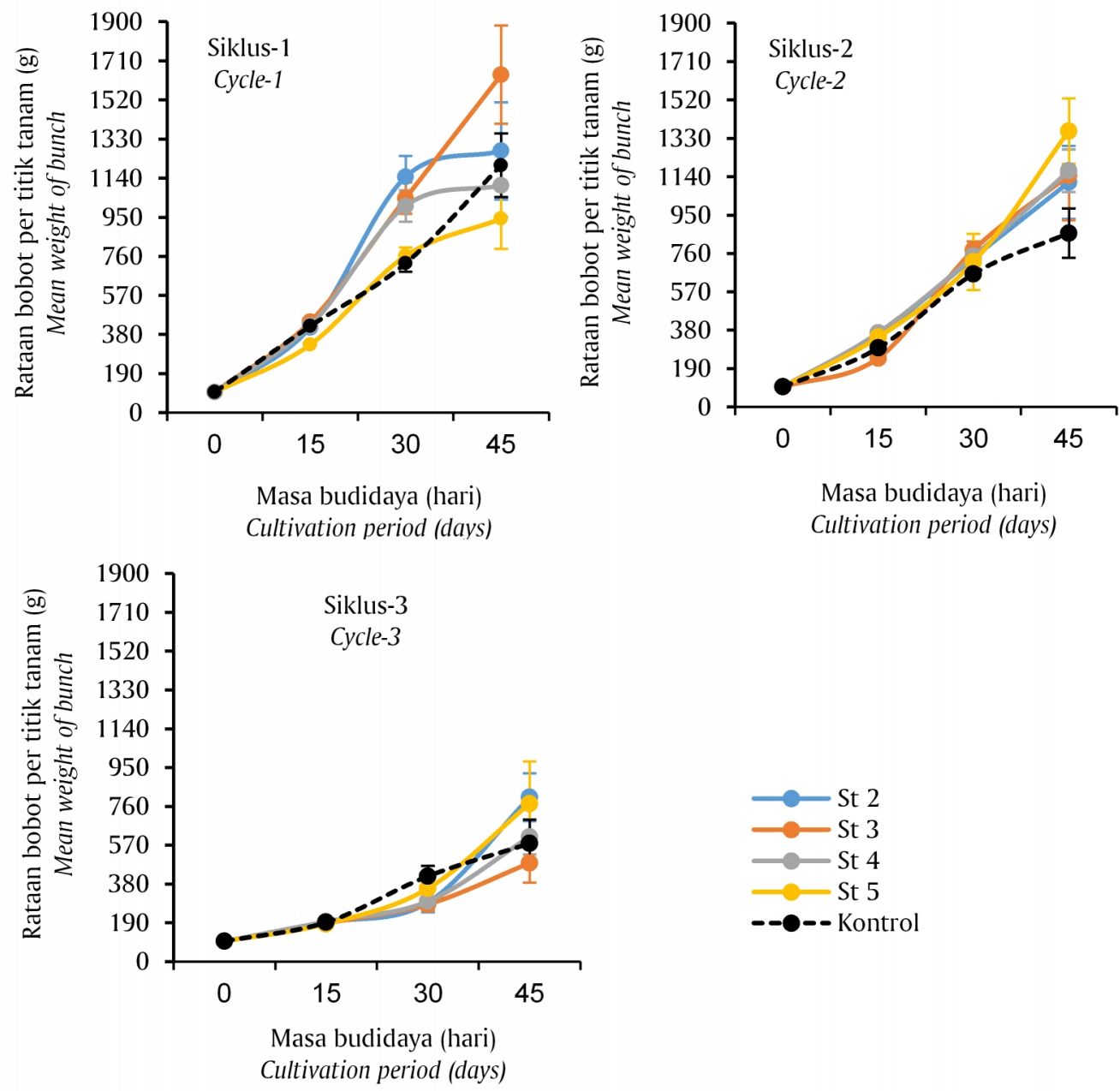

Gambar 4. Performa pertumbuhan rumput laut pada sistem IMTA di Teluk Gerupuk, Lombok Tengah, Nusa Tenggara Barat

Figure 4. Growth performance of seaweed on IMTA system at Gerupuk Bay, Central Lombok, West Nusa Tenggara

Tabel 2. Rataan bobot dan laju pertumbuhan harian rumput laut pada tiga siklus musim tanam di Teluk Gerupuk, Lombok Tengah, Nusa Tenggara Barat

Table 2. Mean weight and daily growth rate of seaweed from three cultivation periods in Gerupuk Bay, Central Lombok, West Nusa Tenggara

\begin{tabular}{|c|c|c|c|c|c|c|}
\hline \multirow{2}{*}{$\begin{array}{l}\text { Parameter pertumbuhan } \\
\text { Growth variables }\end{array}$} & \multicolumn{3}{|c|}{ IMTA } & \multicolumn{3}{|c|}{ Kontrol (Control) } \\
\hline & $\begin{array}{l}\text { Siklus-1 } \\
\text { Cycle-1 }\end{array}$ & $\begin{array}{l}\text { Siklus-2 } \\
\text { Cycle-2 }\end{array}$ & $\begin{array}{l}\text { Siklus-3 } \\
\text { Cycle-3 }\end{array}$ & $\begin{array}{l}\text { Siklus-1 } \\
\text { Cycle-1 }\end{array}$ & $\begin{array}{l}\text { Siklus-2 } \\
\text { Cycle-2 }\end{array}$ & $\begin{array}{l}\text { Siklus-3 } \\
\text { Cycle-3 }\end{array}$ \\
\hline Rataan bobot akhir (Mean weight) (g) & $1,240.53$ & $1,546.85$ & 668.45 & 1202.6 & 860.80 & 579.00 \\
\hline $\begin{array}{l}\text { Laju pertumbuhan harian (\%/hari) } \\
\text { Daily growth rate (DGR) (\%/days) }\end{array}$ & 5.60 & 6.09 & 4.22 & 5.53 & 4.78 & 3.90 \\
\hline
\end{tabular}

kerja enzim yang berperan dalam fotosintesis sehingga dapat meningkatkan laju pertumbuhan, dan aktivitas enzim akan menurun jika peningkatan suhu melebihi batas optimum, sehingga dapat berdampak pada penurunan aktivitas fotosintesis dan laju pertumbuhan pada rumput laut (Dawes, 1981). Selain itu, 

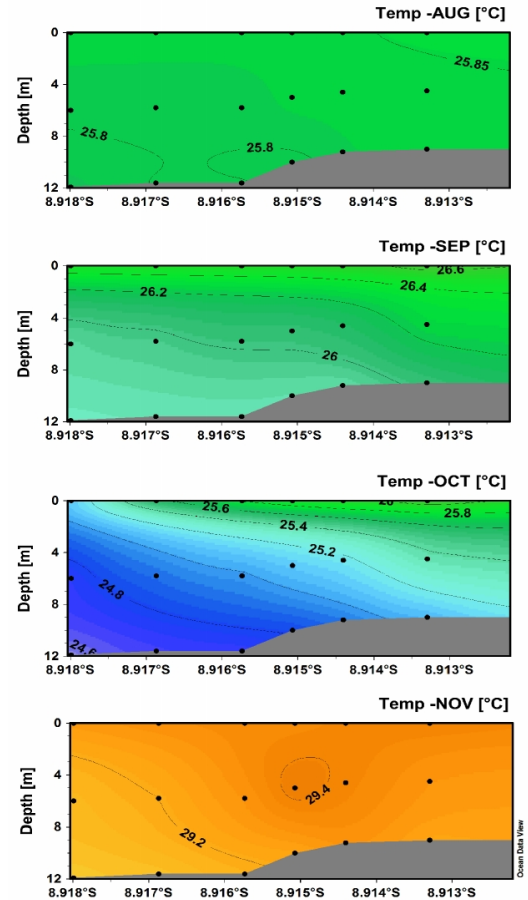

(a)
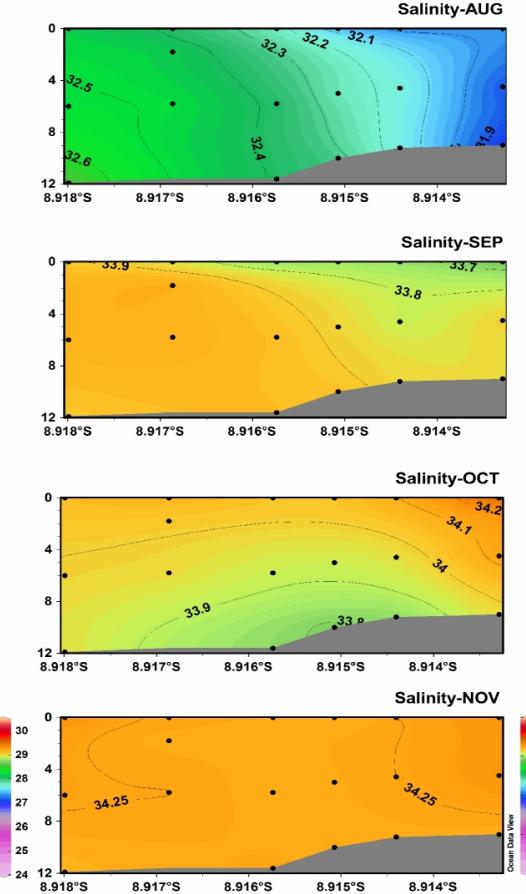

(b)
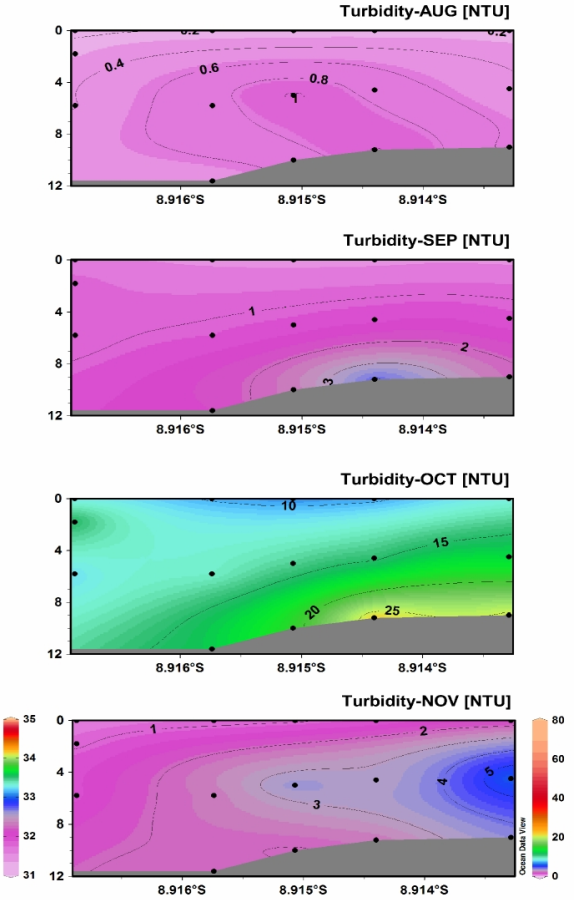

(c)

Gambar 5. Sebaran vertikal suhu (a), salinitas (b), dan kekeruhan (c) bulan Agustus-November pada stasiun pengamatan unit IMTA di Teluk Gerupuk, Lombok Tengah. Stasiun pengamatan disajikan pada Gambar 1a

Figure 5. Vertical distribution of water temperature (a), salinity (b), and turbidity (c) from August-November at the IMTA sampling stasiun in Gerupuk Bay, Central Lombok. Samplings position show in Figure 1a

peningkatan suhu perairan juga akan menyebabkan perubahan pada parameter kualitas air lainnya, seperti $\mathrm{pH}$, salinitas, dan bahan organik terlarut yang sangat berperan pada proses pertumbuhan rumput laut (Dawes, 1981; Effendi, 2003).

Perbedaan pola pertumbuhan harian rumput laut yang ditemukan pada penelitian ini dapat dipengaruhi oleh kondisi lingkungan perairan dan iklim sehingga dapat memengaruhi respons metabolik berupa laju pertumbuhan dan laju fotosintensis (Banerjee et al., 2009). Hasil penelitian Erlania \& Radiarta (2014) juga menemukan pola pertumbuhan yang sama untuk empat strain rumput laut Kappaphycus alvarezii varian Tambalang dan varian Maumere, K. striatum, Eucheuma denticulatum yang dibudidayakan di Teluk Gerupuk tahun 2013 yaitu pada bulan Juli-Oktober memiliki tingkat pertumbuhan dan produktivitas yang baik dibandingkan dengan bulan November-Desember. Kondisi iklim baik lokal maupun global juga berpengaruh terhadap tingkat produktivitas rumput laut yang dibudidayakan. Hasil kajian pola musim tanam di Teluk Gerupuk tahun 2007-2012 (Radiarta et al., 2013), menunjukkan bahwa kisaran bulan JuniOktober merupakan musim produktif untuk budidaya rumput laut.

Pertumbuhan rumput laut di sekitar unit IMTA menunjukkan pola pertumbuhan yang lebih baik dibandingkan dengan kontrol (Gambar 4 dan Tabel 2). Hal ini menjadi indikasi awal terjadinya ekspos nutrien yang berasal dari limbah KJA terhadap rumput laut yang dibudidayakan di sekitar KJA tersebut. Penerapan model IMTA ini merupakan langkah efektif dalam pemanfaatan lingkaran energi (nutrien) yang berpusat pada limbah budidaya ikan sehinga dapat dimanfaatkan oleh spesies penyerap bahan anorganik dan organik seperti rumput laut (Barrington et al., 2009). Hasil penelitian Radiarta et al. (2014) menunjukkan bahwa secara umum peningkatan produksi rumput laut dapat mencapai $74 \%$ melalui sistem budidaya multi-tropik terintegrasi (IMTA), dibandingkan dengan sistem monokultur. Dengan kata lain dapat diartikan bahwa performa pertumbuhan rumput laut yang dibudidayakan dekat KJA ikan akan lebih baik dibandingkan dengan lokasinya yang jauh (kontrol). 
Tabel 3. Performa budidaya ikan pada sistem IMTA di Teluk Gerupuk, Lombok Tengah, Nusa Tenggara Barat

Table 3. Performance of fish cultured in IMTA system at Gerupuk Bay, Central Lombok, West Nusa Tenggara

\begin{tabular}{|c|c|c|}
\hline $\begin{array}{l}\text { Parameter budidaya } \\
\text { Aquaculture variable }\end{array}$ & $\begin{array}{l}\text { Kerapu } \\
\text { Grouper }\end{array}$ & $\begin{array}{c}\text { Bawal bintang } \\
\text { Pompano }\end{array}$ \\
\hline Masa budidaya (hari) (Day of culture) & 150 & 150 \\
\hline $\begin{array}{l}\text { Rataan bobot awal } \\
\text { Mean weight at begining of culture (g) }\end{array}$ & 29.53 & 7.67 \\
\hline $\begin{array}{l}\text { Rataan bobot akhir } \\
\text { Mean weight at the end of culture (g) }\end{array}$ & 173.45 & 161.27 \\
\hline $\begin{array}{l}\text { Rataan panjang awal } \\
\text { Mean lenght at begining of culture }(\mathrm{cm})\end{array}$ & 12.10 & 7.67 \\
\hline $\begin{array}{l}\text { Rataan panjang akhir } \\
\text { Mean lenght at the end of culture }(\mathrm{cm})\end{array}$ & 19.21 & 21.58 \\
\hline Jumlah tebar (ekor) (Number of fish) & 3,950 & 4,420 \\
\hline Jumlah ikan mati (ekor) (Mortality) & 881 & 1,286 \\
\hline Sintasan (Survival rate) $(\%)$ & 77.70 & 70.90 \\
\hline $\begin{array}{l}\text { Laju pertumbuhan spesifik (\%/hari) } \\
\text { Specific growth rate (SGR) (\%/days) }\end{array}$ & 1.18 & 2.03 \\
\hline $\begin{array}{l}\text { Biomassa awal } \\
\text { Biomass at begining of culture (kg) }\end{array}$ & 116.66 & 33.89 \\
\hline $\begin{array}{l}\text { Biomassa akhir } \\
\text { Biomass at the end of culture (kg) }\end{array}$ & 532.33 & 505.41 \\
\hline Konsumsi pakan (Feed consumption ) (kg) & 1,529 & 932 \\
\hline Rasio konversi pakan (Feed convertion ratio ) (FCR) & 3.68 & 1.98 \\
\hline
\end{tabular}

Tabel 4. Performa budidaya rumput laut pada sistem IMTA di Teluk Gerupuk, Lombok Tengah, Nusa Tenggara Barat

Table 4. Performance of seaweed cultured in IMTA system at Gerupuk Bay, Central Lombok, West Nusa Tenggara

\begin{tabular}{lcc}
\hline \multicolumn{1}{c}{$\begin{array}{c}\text { Parameter budidaya } \\
\text { Aquaculture variable }\end{array}$} & IMTA & $\begin{array}{c}\text { Kontrol } \\
\text { Control }\end{array}$ \\
\hline Ukuran rakit (Size of raft) & \multicolumn{2}{c}{$7 \mathrm{~m} \mathrm{x} \mathrm{7} \mathrm{m}$} \\
Jumlah tali ris/rakit (Number of lines/raft) & \multicolumn{2}{c}{35} \\
Jumlah titik tanam/rakit (Number sedling points/raft) & \multicolumn{2}{c}{1,225} \\
Biomassa awal (Biomass at the begining of culture) $(\mathrm{kg})$ & \multicolumn{2}{c}{122.5} \\
Masa budidaya (hari/siklus) (Days of culture) (days/ciycle) & \multicolumn{2}{c}{100} \\
Rataan bobot awal (Mean weight at the begining of culture) (g) & \multicolumn{2}{c}{100} \\
Rataan bobot akhir (Mean weight at the end of culture) $(\mathrm{g})$ & $668.45-1,546.85$ & $579.00-1,202.6$ \\
Biomassa akhir (Biomass at the end of culture) $(\mathrm{kg})$ & $818.85-1,894.89$ & $709.28-1,473.19$ \\
Pertambahan biomassa (Increased of biomass) $(\mathrm{kg})$ & $696.35-1,772.39$ & $586.78-1,350.69$ \\
Pertumbuhan harian (\%/hari) (Daily growth rate) (\%/days) & $4.22-6.09$ & $3.90-5.53$ \\
\hline
\end{tabular}




\section{Peningkatan Produktivitas Budidaya pada Sistem IMTA}

Ringkasan perfoma masing-masing komoditas budidaya pada sistem IMTA ditampilkan pada Tabel 3 dan 4. Secara prinsip, proses budidaya ikan sebagai komoditas primer pada sistem IMTA diharapkan minimal berlangsung sebagaimana halnya pada budidaya ikan secara monokultur, dengan performa mengikuti tren pertumbuhan pada umumnya. Sementara yang menjadi nilai tambah dari sistem IMTA adalah dihasilkannya biomassa dari komoditas sekunder (seperti ikan herbivora, rumput laut, kekerangan, teripang) dari limbah organik budidaya ikan yang menjadi tambahan dari nilai produksi budidaya ikan itu sendiri sebagai produk utama (Barringon et al., 2009). Selain itu, dengan termanfaatkannya limbah budidaya ikan yang masuk ke perairan oleh komoditas lainnya yaitu spesies penyerap bahan organik dan anorganik, maka sistem IMTA memberikan fungsi tambahan terhadap lingkungan perairan dalam mengurangi pencemaran perairan akibat limbah budidaya ikan itu sendiri (Yuniarsih et al., 2014; Irisarri et al., 2015). Dengan demikian, secara tidak langsung sistem IMTA akan berperan memperbaiki kondisi lingkungan perairan di mana aktivitas IMTA tersebut dilakukan. Dengan kondisi lingkungan perairan yang lebih baik, maka ikan sebagai komoditas utama pada sistem IMTA dimungkinkan untuk memberikan performa yang lebih baik dibandingkan pada sistem monokultur.

Menurut Neori et al. (2000), ide yang tergambar dari kondisi budidaya dengan sistem IMTA ini yaitu tingginya pertumbuhan rumput laut didukung oleh terdapatnya amonia yang diekskresikan oleh ikan ke lingkungan; di mana rumput laut juga berperan dalam memfiltrasi amonia dari lingkungan perairan. Sistem IMTA merupakan sistem budidaya yang didesain untuk mengurangi permasalahan lingkungan perairan yang disebabkan oleh dampak penggunaan pakan dalam kegiatan budidaya (Abreu et al., 2009). IMTA dapat menjadi opsi pengembangan budidaya laut karena selain dapat meningkatkan produksi dari beberapa komoditas secara simultan juga dapat meminimalkan dampak negatif terhadap lingkungan perairan (Barrington et al., 2009). Konsep penerapan IMTA adalah dengan memperhatikan tingkat trofik dari komoditas yang dibudidayakan, sehingga aliran energi yang tersedia dalam unit IMTA tersebut dapat dimanfaatkan secara maksimal, dan aktivitas budidaya dapat berkelanjutan.

\section{KESIMPULAN}

Hasil penelitian penerapan model IMTA di Teluk Gerupuk, Lombok Tengah dengan memadukan antara budidaya ikan kerapu macan, ikan bawal bintang, dan rumput laut menunjukkan produktivitas budidaya yang baik, ditandai dengan performa pertumbuhan semua komoditas budidaya yang baik. Pertumbuhan rumput laut sekitar unit IMTA lebih tinggi dibandingkan dengan unit rumput laut kontrol (jarak 2-3 km dari unit IMTA); merupakan salah satu indikasi efisiensi pemanfaatan sebaran nutrien yang merupakan limbah budidaya dari KJA ikan yang terbuang ke dalam perairan. Hasil dari penelitian ini menunjukkan secara jelas bahwa penerapan model IMTA dalam pengembangan budidaya laut sangat relevan baik dari segi pemanfaatan lahan, hasil produksi, dan kondisi lingkungan perairan. Pola pengembangan IMTA ini dapat diterapkan di lokasi dengan keterbatasan lahan potensial, namun tersedianya komoditas unggulan untuk dikembangkan. Hasil dari penelitian ini diharapkan dapat menjadi model pengembangan budidaya laut yang berwawasan lingkungan.

\section{UCAPAN TERIMA KASIH}

Penulis mengucapkan terima kasih kepada Balai Perikanan Budidaya Laut (BPBL) Lombok atas bantuannya selama kegiatan lapangan. Kami juga mengucapkan terima kasih kepada teknisi budidaya laut unit IMTA di Gerupuk yang telah membantu kelancaran pengumpulan data selama penelitian. Penelitian ini dibiayai oleh SINAS RISTEK T.A. 2015.

\section{DAFTAR ACUAN}

Abreu, M.H., Varela, D.A., Henríquez, L., Villarroel, A., Yarish, C., Sousa-Pinto, I., \& Buschmann, A.H. (2009). Traditional vs. integrated multi-trophic aquaculture of Gracilaria chilensis. Bird, C.J., McLachlan, J., \& Oliveira, E.C.: Productivity and physiological performance. Aquaculture, 293, 211220.

Alexander, K.A., Angel, D., Freeman, S., Israel, D., Johansen, J., Kletou, D., Meland, M., Pecorino, D., Rebours, C., Rousou, M., Shorten, M., \& Potts, T. (2016). Improving sustainability of aquaculture in Europe: Stakeholder dialogues on integrated multi-trophic aquaculture (IMTA). Environmental Science \& Policy, 55, 96-106.

Anonim. (2011). Pijar. Evaluasi kegiatan program 2011 dan rencana kinerja tahun 2012. Pemerintah Provinsi Nusa Tenggara Barat, $71 \mathrm{hlm}$. 
Anonim. (2016). Laporan khusus. Upaya meraih pertumbuhan $15 \%$ per tahun. Majalah Info Akuakultur, Edisi No. 12/Tahun I/15 Januari 2016, hlm. 14-17.

Banerjee, K., Ghosh, R., Homechaudhuri, S., \& Mitra, A. (2009). Seasonal variation in the biochemical composition of red seaweed (Catenella repens) from Gangetic delta, northeast coast of India. J. Earth Syst. Sci., 118(5), 497-505.

Barrington, K., Chopin, T., \& Robinson, S. (2009). Integrated multi-trophic aquaculture (IMTA) in marine temperate waters. In Soto, D. (Ed.). Integrated mariculture: a global review. FAO Fisheries and Aquaculture Technical Paper No. 529. FAO. Rome, p. 7-46.

Chopin, T., \& Robinson, S. (2006). Rationale for developing integrated multi-trophic aquaculture (IMTA): an example from Canada. Fish Farmer, January/February, p. 20-21.

Chopin, T., Troell, M., Reid, G.K., Nowler, D., Robinson, S.M.C., Neori, A., Buschmann, A.H., \& Pang, S. (2010). Integrated multi-trophic aquaculture. Part II. Increasing IMTA adoption. Global Aquaculture Advocate, November/December, p. 1720.

Costa-Pierce, B. (2008). An ecosystem approach to marine aquaculture: a global review. In Soto, D., Aguilar-Manjarrez, J., \& Hishamunda, N. (Eds.). Building an ecosystem approach to aquaculture. FAO Fisheries and Aquaculture Proceedings. No. 14. FAO. Rome, p. 81-155.

Dharma, T.S., Wibawa, G.S., \& Setiadi, I. (2013). Performa pertumbuhan benih ikan bawal, Trachinotus blocii (Lacepede) pada penggelondongan dalam hafa di tambak. Prosiding Pertemuan Ilmiah Nasional Tahunan X ISOI 2013. hlm. 296-300.

Dawes, C.J. (1981). Marine botany. John Wiley and Sons, Inc. Canada, 628 pp.

Effendie, M.I. (1979). Metode biologi perikanan. Cetakan pertama. Yayasan Dwi Sri. Bogor, $112 \mathrm{hlm}$.

Effendi, H. (2003). Telaah kualitas air bagi pengelolaan sumberdaya dan lingkungan perairan. Kanisius. Yogyakarta, $258 \mathrm{hlm}$.

Erlania, \& Radiarta, I N. (2014). Perbedaan musim tanam terhadap performa budidaya empat varian rumput laut eucheumatoids di Teluk Gerupuk, Nusa Tenggara Barat. J. Ris. Akuakultur, 9(2), 331-342.

Hayasi, L., Yokoya, N.S., Ostini, S., Pereira, R.T.L., Braga, E.S., \& Oliveira, E.C. (2008). Nutrients removed by Kappaphycus alvarezii (Rhodophyta, Solieriaceae) in integrated cultivation with fishes in re-circulating water. Aquaculture, 277, 185-191.
Ismi, S., Asih, Y.N., Kusumawati, D., \& Prihadi, T.H. (2012). Pendederan benih kerapu sebagai usaha untuk meningkatkan pendapatan masyarakat pesisir. Prosiding InSINas 2012, hlm. 312-318.

Irisarri, J., Fernandez-Reiriz, M.J., Labarta, U., Cranford, P.J., \& Robinson, S.M.C. (2015). Availability and utilization of waste fish feed by mussels Mytilus edulis in a commercial integrated multitrophic aquaculture (IMTA) system: A multi-indicator assessment approach. Ecological Indicators, 48, 673-686.

Jayakumar, R., Nazar, A.K.A., Tamilmani, G., Sakthivel, M., Kalidas, C., Ramesh, K.P., Rao, G.H., \& Gopakumar, G. (2014). Evaluation of growth and production performance of hatchery produced silver pompano Trachinotus blochii (Lacépède, 1801) fingerlings under brackishwater pond farming in India. Indian J. of Fisheries, 61(3), 58-62.

Juniyanto, N.M., Akbar, S., \& Zakimin. (2008). Breeding and seed production of silver pompano (Trachinotus blochii, Lacepede) at the Mariculture Development Center of Batam. Aquaculture Asia Magazine, XII(2), 46-48.

Kementerian Kelautan dan Perikanan [KKP]. (2014). Blue economy: pembangunan kelautan dan perikanan berkelanjutan. Kementerian Kelautan dan Perikanan. Jakarta, $240 \mathrm{hlm}$.

Lander, T.R., Robinson, S.M.C., MacDonald, B.A., \& Martin, J.D. (2013). Characterization of the suspended organic particles released from salmon farms and their potential as a food supply for the suspension feeder, Mytilus edulis in integrated multi-trophic aquaculture (IMTA) systems. Aquaculture, 406-407, 160-171.

Luining, K. (1990). Seaweed: Their environment, biogeography, and ecophysiology. John Wiley \& Sons, Inc. Canada, 527 pp.

Martinez-Espineira, R., Chopin, T., Robinson, S., Noce, A., Knowler, D., \& Yip, W. (2015). Estimating the biomitigation benefits of integrated multi-trophic aquaculture: A contigent behaviour analysis. Aquaculture, 437, 182-194.

Neori, A., Spigel, M., \& Ben-Ezra, D. (2000). A sustainable integrated system for culture of fish, seaweed and abalone. Aquaculture, 186, 297-291.

Parenrengi, A., Rachmansyah, \& Suryati, E. (2011). Budidaya rumput laut penghasil karaginan (karaginofit). Edisi Revisi. Balai Riset Perikanan Budidaya Air Payau, Badan Penelitian dan Pengembangan Kelautan dan Perikanan, Kementerian Kelautan dan Perikanan. Jakarta, 54 hlm. 
Radiarta, I N., Erlania, \& Rusman. (2013). Pengaruh iklim terhadap musim tanam rumput laut, Kappaphycus alvarezii di Teluk Gerupuk Kabupaten Lombok Tengah, Nusa Tenggara Barat. J. Ris. Akuakultur, 8(3), 453-464.

Radiarta, I N., Erlania, \& Sugama, K. (2014). Budidaya rumput laut, Kappaphycus alvarezii secara terintegrasi dengan ikan kerapu di Teluk Gerupuk Kabupaten Lombok Tengah, Nusa Tenggara Barat. J. Ris. Akuakultur, 9(1), 125-134.

Radiarta, I N., \& Erlania. (2015). Indeks kualitas air dan sebaran nutrien sekitar budidaya laut terintegrasi di perairan Teluk Ekas, Nusa Tenggara Barat: aspek penting budidaya laut. J. Ris. Akuakultur, 10(1), 141-152.

Radiarta, I N. (2015). Site selection and carrying capacity for marine finfish and seaweeds aquaculture in Gerupuk Bay and Sereweh Bay, Lombok, West Nusa Tenggara. FAO Report (Unpublished), 33 pp.

Reid, G.K., Chopin, T., Robinson, S.M.C., Azevedo, P., Quinton, M., \& Belyea, E. (2013). Weight ratios of the kelps, Alaria esculenta and Saccharina latissima, required to sequester dissolved inorganic nutreints and supply oxygen for Atlantic salmon, Salmo salar, in integrated multi-trophic aquaculture systems. Aquaculture, 408-409, 34-46.

Schlitzer, R. (2011). Ocean data View. WWW page. http://odv.awi.de.

Soto, D. (Ed.). (2009). Integrated mariculture: a global review. FAO Fisheries and Aquaculture Technical Paper No. 529. FAO. Rome, 183 pp.
Tang, J-Y., Dai, Y-X., Wang, Y., Qin, J.G., \& Li, Y-M. (2015). Improvement of fish and pearl yields and nutrient utilization efficiency through fish-mussel integration and feed supplementation. Aquaculture, 448, 321-326.

Tarunamulia, Hasnawi, Antoni, R., Mustafa, A., \& Paena, M. (2015). Perspektif pengembangan budidaya perikanan berdasarkan karakteristik pantai di Teluk Gerupuk dan Teluk Bumbang Kabupaten Lombok Tengah, Provinsi Nusa Tenggara Barat. J. Ris. Akuakultur, 10(1), 117-126.

Troell, M., Halling, C., Nilsson, A., Buschmann, A.H., Kautsky, N., \& Kautsky, L. (1997). Integrated marine cultivation of Gracilaria chilensis (Gracilariales, Rhodophyta) and salmon cages for reduced environmental impact and increased economic output. Aquaculture, 156, 45-61.

Troell, M. (2009). Integrated marine and brackishwater aquaculture in tropical regions: research, implementation and prospects. In Soto, D. (Ed.). Integrated mariculture: a global review. FAO Fisheries and Aquaculture Technical Paper No. 529. FAO. Rome, p. 47-131.

Troell, M., Joyce, A., Chopin, T., Neoru, A, Bushmann, A.H., \& Fang, J-G. (2009). Ecological engineering in aquaculture-potential for integrated multitrophic aquaculture (IMTA) in marine offshore systems. Aquaculture, 297, 1-9.

Yuniarsih, E., Nirmala, K., \& Radiarta, I N. (2014). Tingkat penyerapan nitrogen dan fosfor pada budidaya rumput laut berbasis IMTA (integrated multi-trophic aquaculture) di Teluk Gerupuk, Lombok Tengah, Nusa Tenggara Barat. J. Ris. Akuakultur, 9(3), 487-501. 